\title{
Case study: risk associated to wearing silver or graphene nanoparticle-coated facemasks for protection against COVID-19
}

\author{
Carmen Estevan $^{1} \cdot$ Eugenio Vilanova ${ }^{1} \cdot$ Miguel A. Sogorb ${ }^{1}$ (1)
}

Received: 7 October 2021 / Accepted: 28 October 2021 / Published online: 16 November 2021

(c) The Author(s) 2021

\begin{abstract}
The world is living a pandemic situation derived from the worldwide spreading of SARS-CoV-2 virus causing COVID19. Facemasks have proven to be one of the most effective prophylactic measures to avoid the infection that has made that wearing of facemasks has become mandatory in most of the developed countries. Silver and graphene nanoparticles have proven to have antimicrobial properties and are used as coating of these facemasks to increase the effectivity of the textile fibres. In the case of silver nanoparticles, we have estimated that in a real scenario the systemic (internal) exposure derived from wearing these silver nanoparticle facemasks would be between $7.0 \times 10^{-5}$ and $2.8 \times 10^{-4} \mathrm{mg} / \mathrm{kg}$ bw/day. In addition, we estimated conservative systemic no effect levels between 0.075 and $0.01 \mathrm{mg} / \mathrm{kg}$ bw/day. Therefore, we estimate that the chronic exposure to silver nanoparticles derived form facemasks wearing is safe. In the case of graphene, we detected important gaps in the database, especially regarding toxicokinetics, which prevents the derivation of a systemic no effect level. Nevertheless, the qualitative approach suggests that the risk of dermal repeated exposure to graphene is very low, or even negligible. We estimated that for both nanomaterials, the risk of skin sensitisation and genotoxicity is also negligible.
\end{abstract}

Keywords Facemasks · Silver nanoparticles · Grapheme · Risk assessment · COVID-19

\section{Introduction}

On December 31 2019, World Health Organization (WHO) ${ }^{1}$ released a note entitled "Pneumonia of unknown cause reported to WHO China Office" ${ }^{2}$ This initially called pneumonia was soon renamed as COVID-19 and is indeed an infectious disease caused by the SARS-CoV-2 virus (Zhu et al. 2020). The virus quickly spread worldwide and on March 11, 2020 WHO declared the COVID-19 outbreak a global pandemic (Cucinotta and Vanelli 2020). In the moment of draft this paper, the number of cases in the world was 235 million with 4.8 million of fatalities (Johns Hopkins Coronavirus Resource Center 2021). The virus has affected to both developed and non-developed countries, being the number of cases in both US and European Union countries of 44 and 37 million, respectively.

The virus spreads through airborne in small liquid particles expelled by infected people when they sneeze, cough,

Miguel A. Sogorb

msogorb@umh.es

1 Instituto de Bioingeniería, Universidad Miguel Hernández de Elche, Avenida de la Universidad s/n, 03202 Elche, Spain speak or breathe (Abd El-Wahab et al. 2020; Morawskaa and Caob 2020). This makes that one of the most effective prophylactic measures against the infection is wearing appropriate facemasks covering mouse and nose. Indeed, Tabatabaeizadeh (2020) found in a meta-analysis with four studies a relative risk of infection when wearing masks of 0.12. Eikenberry and co-workers (2020) modelled that an $80 \%$ adoption of moderately (50\%) effective masks in the State of New York could reduce, in certain moment of the pandemic, the peak daily death rate by $34 \%-58 \%$. Another review found a link between mouth and nose covering and relevant protection against the pathogen (Matuschek et al.

\footnotetext{
${ }^{1}$ Abbreviations: CLP $=$ Classification, Labelling and Packaging; DNEL $=$ Derived systemic No Effect Level; ECHA =European Chemical Agency; GLP $=$ Good Laboratory Practice; GQD-PEG $=$ Polyethylene glycol graphene quantum; LOAEL $=$ Lowest Observed Adverse Effect Level; NMs=Nanomaterials; NOAEL $=$ No Observed Adverse Effect Level; NPs = Nanoparticles; $\mathrm{OECD}=$ Organisation for Economic Cooperation and Development; $\mathrm{RCR}=$ Risk Characterisation Ratio; $\mathrm{SCCS}=$ Scientific Committee on Consumer Safety; SCENIHR = Scientific Committee on Emerging and Newly Identified Health Risks; WHO = World Health Organization.

2 https://www.who.int/emergencies/diseases/novel-coronavirus-2019/ events-as-they-happen (accessed last time on October 6, 2021).
} 
2020). All these evidences induced Governments to declare facemask-wearing mandatory in different spaces, especially in indoor areas.

Novel designs of respiratory protection equipment and facemasks include the coating of natural fibres initially used as filter barriers with certain nanomaterials (NMs), since the antimicrobial properties of several NMs was largely known (O'Dowd et al. 2020). Two of the NMs most widely used in facemasks are silver nanoparticles (NPs) (Ramaiah et al. 2021) and graphene (Srivastava et al. 2020).

Due to the above-stated considerations about the mandatory use of facemasks, since the outbreak of the virus to today there have been, and still there are, hundreds of millions of people regularly wearing facemasks. This massive use in general population and in occupational settings raised a concern as regard the safety of the facemasks coated with NMs. Indeed, the Canada Government released an announcement on May 2, 2021 alerting that facemasks that contain graphene may pose health risks; this announcement was updated on July 13 and on September 282021 with lists of model number of graphene-based authorised facemasks. ${ }^{3}$

Overall, the risk assessment associated to facemask wearing is strongly advisable. In this manuscript, we assess, based on publically available information and following methodologies used by European Regulatory Agencies, the potential risk for general population and workers of wearing facemasks coated with silver and graphene NMs. In the case of silver NPs, since the available information was found for oral administration and in the exposure scenario of our interest the route of exposure is dermal, we derived a systemic no effect level (DNEL). The derived systemic DNELs were several orders of magnitude higher than the estimated exposures; suggesting that, despite the uncertainties, the use of facemasks coated with silver NPs is safe. The lack of data made impossible to take a similar approach for graphene NMs, although a qualitative risk assessment suggests that the probability of appearance of adverse effects derived from chronic exposure to graphene during facemask wearing is extremely low.

\section{Case 1: silver nanoparticles}

\section{Hazard identification}

\section{Threshold effects after repeated exposure}

Organisation for Economic Cooperation and Development (OECD) (2017) reviewed the repeated dose toxicity studies

\footnotetext{
3 https://healthycanadians.gc.ca/recall-alert-rappel-avis/hc-sc/2021/ 75309a-eng.php (accessed last time on October 6, 2021).
}

in animals with silver NPs finding five different studies (studies $1-5$ in Table 1). We additionally screened open scientific literature finding two of the studies previously reviewed by OECD (studies 2 and 3 in Table 1) plus two additional studies (studies 6 and 7 in Table 1).

Studies 1, 4, 5 and 6 failed in the induction of toxic effects and therefore were not suitable for settings accurate no observed adverse effect level (NOAEL) or lowest observed adverse effect level (LOAEL) (Table 1). The approach of study 2 (Jeong et al. 2010) is histopathological with semiquantitative end points and, therefore, cannot be used for setting NOAEL or LOAEL.

On the opposite of the above-stated studies, the studies 3 and 7 were able to set NOAEL or LOAEL. We considered these two studies as key studies for estimating a systemic DNEL. It is well known that one of the main clinical effects derived from the silver exposure is argyria (permanent bluish-gray discoloration of the skin or eyes). However, these studies determined that liver is the target of silver NPs. Kim and co-workers (2010) determined in a 90-day exposure study a NOAEL of $30 \mathrm{mg} / \mathrm{kg}$ bw/day based on the bile-duct hyperplasia together with slight haematological alterations consistent with hepatic injuries reported at $125 \mathrm{mg} / \mathrm{kg}$ bw/ day (Table 1). Yu and co-workers (2004) reported in a teratogenicity study in rats maternal hepatotoxicity at $1000 \mathrm{mg} /$ $\mathrm{kg}$ bw/day causing oxidative stress in hepatic tissues of pregnant females and set this dose as LOAEL (Table 2). Overall, we consider as key studies for setting systemic DNEL the studies 3 and 7 in Table 1.

\section{Skin sensitisation}

OECD (2017) reviewed two different regulatory studies with citrate capped Ag NPs according to OECD TG 406. In one of these studies, $0.4 \mathrm{ml}$ of Ag NPs of unknown concentration were used for induction and no skin reaction was observed in any of the treated groups 24 and $48 \mathrm{~h}$ after the challenge. In the second study, a presumably more severe induction was used (three pairs of intradermal injections of $0.1 \mathrm{ml}$ of $20.48 \%$ silver NPs preparation), and 1/20 test animals exhibited grade 1 erythema 24 or $48 \mathrm{~h}$ after challenge. Altogether, the available database suggests that Ag NPs could act as weak skin sensitiser.

\section{Genotoxicity}

The Scientific Committee on Emerging and Newly Identified Health Risks (SCENIHR) (2014) reviewed the health effects and safety of nanosilver. In this opinion, SCENIHR compiled a number of in vitro assays showing positive results in formation of bulky DNA adducts, DNA damage induction, comet assay and micronuclei formation. These positive results were reported at minimum concentrations ranging 
Table 1 Summary of repeated dose toxicity studies in rats with silver

\begin{tabular}{|c|c|c|c|}
\hline Study & Method & Results & Reference \\
\hline $1 *$ & $\begin{array}{l}\text { Citrate-capped silver NPs } \\
\text { Sprague-Dawley } \\
\text { rats } \\
50 / \text { sex/dose } \\
62.5,125 \text { and } 250 \\
\mathrm{mg} / \mathrm{kg} \text { bw/day } \\
\text { Gavage } \\
42 \text { days } \\
\text { OECD TG } 422\end{array}$ & $\begin{array}{l}\text { No signification toxicity or mortality } \\
\text { No significant differences in body weight, food and water consumption in any of the } \\
\text { dose groups } \\
\text { No statistically significant changes in haematological analysis in any of the treatment } \\
\text { groups } \\
\text { In the serum biochemical analysis and urinalysis, no treatment related changes } \\
\text { No gross or histopathological findings at necropsy } \\
\text { NOAEL } \geq 250 \mathrm{mg} / \mathrm{kg} \text { bw/day }\end{array}$ & $\begin{array}{l}\text { OECD } \\
\quad(2017)\end{array}$ \\
\hline 2 & $\begin{array}{l}\text { Citrate-capped silver NPs }(60 \mathrm{~nm}) \\
\text { Sprague-Dawley } \\
\text { Rats } \\
10 \text { females/group } \\
30,300,1,000 \mathrm{mg} / \mathrm{kg} / \text { day } \\
\text { Gavage } \\
28 \text { days } \\
\text { OECD TG } 407 \\
\text { GLP }\end{array}$ & $\begin{array}{l}\text { Discharge of mucus granules and an abnormal mucus composition in the goblet cells } \\
\text { in the intestines } \\
\text { No NOAEL could be derived }\end{array}$ & $\begin{array}{l}\text { Jeong } \\
\text { et al. } \\
(2010)\end{array}$ \\
\hline 3 & $\begin{array}{l}\text { Citrate-capped silver NPs }(60 \mathrm{~nm}) \\
\text { Fischer } 344 \text { rats } \\
10 / \mathrm{sex} / \text { dose } \\
0,30,125 \text { and } 500 \mathrm{mg} / \mathrm{kg} \text { bw/day } \\
\text { Gavage } \\
90 \text { days } \\
\text { OECD TG } 408 \\
\text { GLP }\end{array}$ & $\begin{array}{l}\text { No mortality or clinical signs } \\
\text { Decrease in body weight gain in male rats treated with } 500 \mathrm{mg} / \mathrm{kg} \text { bw/day } \\
\text { No significant differences in food and water consumption between treated and control } \\
\text { groups } \\
\text { Significant dose-dependent changes in alkaline phosphatase and cholesterol for males } \\
\text { and females, suggesting slight liver damage starting at } 125 \mathrm{mg} / \mathrm{kg} \text { bw/day } \\
\text { Histopathologic examination revealed a higher incidence of bile-duct hyperplasia, } \\
\text { with or without necrosis, fibrosis, and/or pigmentation starting at } 125 \mathrm{mg} / \mathrm{kg} \text { bw but } \\
\text { without clear dose-response } \\
\text { twofold increase of silver accumulation in female kidneys compared to male kidneys } \\
\text { NOAEL }=30 \mathrm{mg} / \mathrm{kg} \text { bw/day } \\
\text { LOAEL }=125 \mathrm{mg} / \mathrm{kg} \text { bw/day }\end{array}$ & $\begin{array}{l}\text { Kim et al. } \\
(2010) \\
\text { Key study }\end{array}$ \\
\hline $4^{*}$ & $\begin{array}{l}\text { Citrate-capped silver NPs } \\
\text { Sprague-Dawley rats } \\
5 / \text { sex/dose } \\
0,25,100 \text { and } 400 \mathrm{mg} / \mathrm{kg} \text { bw/day } \\
\text { Drinking water } \\
28 \text { days } \\
\text { OECD TG } 407 \\
\text { non-GLP }\end{array}$ & $\begin{array}{l}\text { No significant toxicity or mortality } \\
\text { No significant difference in body weight in any of the dose groups } \\
\text { NOAEL } \geq 400 \mathrm{mg} / \mathrm{kg} \text { bw/day }\end{array}$ & $\begin{array}{l}\text { OECD } \\
(2017)\end{array}$ \\
\hline $5^{*}$ & $\begin{array}{l}\text { Citrate-capped silver NPs } \\
\text { Sprague-Dawley rats } \\
10 / \text { sex/dose } \\
0,25,100 \text { and } 400 \mathrm{mg} / \mathrm{kg} \mathrm{bw} / \text { day } \\
\text { Drinking water } \\
90 \text { days } \\
\text { OECD TG } 408\end{array}$ & $\begin{array}{l}\text { No significant toxicity or mortality } \\
\text { No significant difference in body weight in any of the dose groups } \\
\text { NOAEL } \geq 400 \mathrm{mg} / \mathrm{kg} \text { bw/day }\end{array}$ & $\begin{array}{l}\text { OECD } \\
\quad(2017)\end{array}$ \\
\hline 6 & $\begin{array}{l}\text { Polyvinylpyrrolidone-coated silver } \\
\text { NPs ( } 14 \mathrm{~nm}) \\
\text { Wistar rats } \\
2.25 \mathrm{mg} / \mathrm{kg} \text { bw/day ( } 8 \text { females }) \\
4.5 \mathrm{mg} / \mathrm{kg} \text { bw/day ( } 8 \text { females }) \\
9 \mathrm{mg} / \mathrm{kg} \mathrm{bw} / \text { day }(10 \text { females }+6 \\
\text { males) } \\
\text { Gavage } \\
28 \text { days }\end{array}$ & $\begin{array}{l}\text { Clinical, haematological and biochemical parameters, organ weights, macro- and } \\
\text { microscopic pathological changes were investigated } \\
\text { Faecal bacterial phyla and their silver resistance genes were quantified } \\
\text { No toxicological effects } \\
\text { NOAEL } \geq 9 \mathrm{mg} / \mathrm{kg} \text { bw/day }\end{array}$ & $\begin{array}{l}\text { Hadrup } \\
\text { and Lam } \\
\text { (2014) }\end{array}$ \\
\hline 7 & $\begin{array}{l}\text { Silver NPs }(7.5 \pm 2.5 \mathrm{~nm}) \\
\text { Pregnant Sprague-Dawley rats } \\
11 \text { dams/dose } \\
0,100,300 \text { and } 1000 \mathrm{mg} / \mathrm{kg} \text { bw/day } \\
\text { Gavage } \\
14 \text { days (gestation days } 6-19)\end{array}$ & $\begin{array}{l}\text { Dams: oxidative stress in hepatic tissues at } \geq 100 \mathrm{mg} / \mathrm{kg} / \mathrm{day} \\
\text { Foetuses: No teratogenicity or developmental toxicity at doses of up to } 1000 \mathrm{mg} / \mathrm{kg} / \\
\text { day } \\
\text { LOAEL adults }=100 \mathrm{mg} / \mathrm{kg} \mathrm{bw} / \mathrm{day} \\
\text { NOAEL foetuses }=1000 \mathrm{mg} / \mathrm{kg} \mathrm{bw} / \text { day }\end{array}$ & $\begin{array}{l}\text { Yu et al. } \\
\text { (2014) } \\
\text { Key study }\end{array}$ \\
\hline
\end{tabular}

NPs. * = Non-available original study, data extracted from OECD (2017) 
Table 2 Systemic exposure to silver NPs in silver NP-coated facemask

\begin{tabular}{lll}
\hline & General population & Workers \\
\hline Silver NPs flux $\left(\mathrm{ng} / \mathrm{cm}^{2} / \mathrm{h}\right)$ & 3.8 & 3.8 \\
Time of exposure $(\mathrm{h})$ & 2 & 8 \\
Exposure surface $\left(\mathrm{cm}^{2}\right)$ & 555 & 555 \\
Pass ng to $\mathrm{mg}$ & $10^{-6}$ & $10^{-6}$ \\
Body weight & 60 & 60 \\
Systemic exposure $(\mathrm{mg} / \mathrm{kg}$ bw/day $)$ & $7.0 \times 10^{-5}$ & $2.8 \times 10^{-4}$ \\
\hline
\end{tabular}

Silver NPs flux was taken from the worst case reported by Bianco and co-workers (2014). The rest of parameters were taken as default values considered in risk assessments performed in ECHA and EPA

between units and hundreds of $\mu \mathrm{g} / \mathrm{ml}$. However, negative in vitro results were found in chromosomal aberration test, gene mutation test, micronuclei formation, DNA damage, comet assay in a quite similar range of concentrations. These contradictory assays were explained by SCENIHR based on methodological differences and NP coatings. Nevertheless, it is remarkable that all these effects were identified in open scientific literature and conducted in most of the cases without observing OECD TG and Good Laboratory Practice procedures (GLP). OECD (2017) reviewed one bacterial reverse mutation and one chromosome aberration test both performed observing OECD TG and GLP showing both negative results.

SCENIHR (2014) overviewed an open study showing a weak positive result in Drosophila melanogaster. Another comet assay conducted in vivo with leukocytes of Wistar rats after intravenous administration of silver NPs showed a consistent DNA damage. Finally, SCENIHR (2014) also reported negative results in Sprague-Dawley rats in the bone marrow erythrocyte micronucleus test after a 28-day oral exposure and after a 90-day inhalation exposure.

OECD (2017) reviewed two in vivo studies performed according to GLP and conducted following OECD TG 474. In a bone marrow micronucleus assay the oral administration of silver NPs up to $1,000 \mathrm{mg} / \mathrm{kg}$ bw/day for 28 days did not increase the incidence of micronuclei formation, suggesting it is not genotoxic under the test conditions. In a second assay, exposure by inhalation up to $2.9 \times 10^{6}$ particles $/ \mathrm{cm}^{3}$ for $6 \mathrm{~h} /$ day, 5 days/week, for 13 weeks did not induce genetic toxicity in male or females. Nevertheless, OECD highlighted that as long as it cannot be demonstrated that the test compound has reached the target tissue, a negative outcome of the test does not guarantee the absence of genotoxicity.

\section{Neurotoxicity}

The neurotoxicity of silver NPs has been studied in vitro using T98G human glioblastoma cells (Fuster et al. 2020). It was found that the cytotoxicity of silver NPs was low since concentrations of $40 \mu \mathrm{g} / \mathrm{ml}$ were unable to reduce viability of T98G by more than $10 \%$ after $72 \mathrm{~h}$ of exposure (Fuster et al. 2020). However, other NPs, as zinc and titanium oxides were more cytotoxic to this cell line than silver NPs (Fuster et al. 2021). Silver NPs were unable to incorporate into T98G cells; however, induced transcriptomic alterations indicative of alterations in neuroinflammation processes and in MAPK pathways (Fuster et al. 2020). It suggests that silver NPs can be potentially neurotoxic considering the critical role of glia in the homeostasis of central nervous system.

\section{Silver NP absorption}

\section{Oral absorption}

We found lack of data for oral absorption of silver NPs in humans. However, it was noted that $18 \%$ of silver acetate oral absorption was reported in a 47 -year-old woman suffering from argyria associated with the excessive use of an oral anti-smoking remedy containing such substance (East et al. 1980; Hadrup and Lam, 2014). Loeschner and co-workers (2011) studied the distribution of silver in rats following 28 days of repeated oral exposure to silver NPs or silver acetate. They found that $63 \% \pm 23 \%$ of silver NP dose was excreted in faeces within a $24-\mathrm{h}$ time period in week 3 of the study, while this record was $49 \% \pm 21 \%$ for silver acetate. It suggests that the oral absorption of silver NPs tends to be slightly lower than the ionic silver, although within the same order of magnitude. Therefore, in absence of other more accurate data, we considered for our purposes the record of $18 \%$ of oral absorption reported by East and co-workers (1980) for silver NPs.

\section{Dermal absorption}

We found in the open literature several in vitro studies assessing the dermal absorption of silver NPs in humans and rats. Shape of the silver NPs seems to be a factor that can determine the dermal absorption, although no big differences were found among different forms of silver NPs. The in vitro absorption in rat skin for rod, spherical and triangular silver NPs after $12 \mathrm{~h}$ were $1.82,1.17$ and $0.52 \mu \mathrm{g} /$ $\mathrm{cm}^{2}$; respectively (Tak et al. 2015).

Larese and co-workers (2009) demonstrated in an in vitro diffusion cell system the permeability of human damaged skin to $25 \mathrm{~nm}$ polyvinylpirrolidone-coated silver NPs. They reported a maximum absorption of $11.6 \mathrm{ng} / \mathrm{cm}^{2} / 24 \mathrm{~h}$ (approximately $0.48 \mathrm{ng} / \mathrm{cm}^{2} / \mathrm{h}$ ). Other studies highlighted 
that silver percutaneous absorption after exposure to silver NPs depends on the graft sample. The permeability of polyvinylpyrrolidone-coated silver NPs $(19 \pm 5 \mathrm{~nm})$ after 24 -h of silver flux in fresh, cryopreserved and glycerolised skins graft were $0.2,0.3$ and $3.8 \mathrm{ng} / \mathrm{cm}^{2} / \mathrm{h}$; respectively (Bianco et al. 2014).

There were no big differences among the reported data with human skin and all data ranged between 0.2 and $3.8 \mathrm{ng} /$ $\mathrm{cm}^{2} / \mathrm{h}$. However, it is noted that silver NPs absorption in rats seems to be higher (in the order of $150 \mathrm{ng} / \mathrm{cm}^{2} / \mathrm{h}$ ) than in humans. In the name of worst realistic approach, we will consider the value reported by Bianco and co-workers (2014) of $3.8 \mathrm{ng} / \mathrm{cm}^{2} / \mathrm{h}$ as key value for our calculations.

\section{Systemic exposure}

The repeated dose toxicity studies summarised in Table 1 employ in all cases oral route. The exposure to silver NPs via facemask wearing is obviously dermal. Thus, to be able to compare critical end points of the key studies shown in Table 1 with the real exposure we need to estimate the systemic (internal) exposure. For such purpose, we used the following equation:

$$
\begin{aligned}
& \text { Systemic exposure }(\mathrm{mg} / \mathrm{kg} \mathrm{bw} / \text { day }) \\
& =\text { Flux }\left(\mathrm{mg} / \mathrm{cm}^{2} / \mathrm{h}\right) \\
& \quad \times \text { surface of exposure }\left(\mathrm{cm}^{2}\right) \\
& \quad \times \text { exposure time }(\mathrm{h}) / \text { body weight } .
\end{aligned}
$$

As commented above as reference value for influx the worst case described by Bianco and co-workers (2014) of $3.8 \mathrm{ng} / \mathrm{cm}^{2} / \mathrm{h}$ will be considered. We will consider for general population and workers 2 and $8 \mathrm{~h}$ of daily exposure; respectively. As regard area of exposure, we are going to consider $555 \mathrm{~cm}^{2}$. This figure is taken from the recommendations of default human factor values for use in exposure assessment for biocidal products used by the European Chemical Agency (ECHA) that refer to US-EPA Human Factors Handbook (2011a). The $555 \mathrm{~cm}^{2}$ value assumes that the whole surface of the face will be covered by the mask. We will use $60 \mathrm{~kg}$ body weight as well according to the same recommendation (US-EPA, 2011b). The estimation of systemic exposure is described in Table 2. The estimated values for general population and workers were $7 \times 10^{-5}$ and $2.8 \times 10^{-4} \mathrm{mg} / \mathrm{kg}$ bw/day; respectively.

\section{Systemic DNEL estimation}

As commented above the exposure to silver NPs through facemask wearing takes place via a different route from those used in the critical end points obtained in Table 1 and, therefore, to compare a derived no effect level (DNEL) with the dermal exposure, we need to use systemic exposures as derived in Table 2 with systemic DNELs. For these DNELs estimation we will use as endpoints the NOAEL and LOAEL obtained in the 90-day oral toxicity study (Kim et al. 2010) (study 3 in Table 1) and the LOAEL obtained for pregnant dams in the teratogenicity study in rats (Yu et al. 2014) (study 7 in Table 1). Other assessment factors were considered according to the ECHA procedures for deriving DNELs for threshold endpoints (ECHA, 2012).

Table 3 shows the results of the systemic DNEL estimation. The endpoint that yielded the highest DNEL was the NOAEL of the 90-day toxicity study, while the LOAEL of the teratogenicity study yielded the lowest DNEL. Estimated systemic DNELs ranged between 0.01 and $0.0375 \mathrm{mg} /$ $\mathrm{kg}$ bw/day for general population and between 0.02 and $0.075 \mathrm{mg} / \mathrm{kg}$ bw/day for workers.

\section{Risk characterisation}

\section{Threshold effects after repeated exposure}

The risk characterisation ratio (RCR) was estimated as the ratio between systemic exposure and the systemic DNEL. Results are shown in Table 4. The RCR estimated for general population was 0.007; while for workers the record was of 0.014 .

As commented above certain neurotoxic effects were reported in vitro after exposure of T98G human glioblastoma cells to silver NPs. The authors reported in this study $0.5 \mu \mathrm{g} / \mathrm{ml}$ the lowest silver NPs concentration able to cause a detectable effect in transcription of certain genes (Fuster et al. 2020). Ministry of Health of Canada Government (2013) reported that the highest (the upper edge of the 95\% confidence interval of the 95th percentile) silver concentration circulating in whole blood in the Canadian population was $0.42 \mu \mathrm{g} / \mathrm{l}(42 \mathrm{ng} / \mathrm{ml})$. This concentration is 2 orders of magnitude than the concentration reported as neurotoxic in vitro and very far from those concentrations that could be reached after facemask wearing.

\section{Skin sensitisation}

The information found suggests that silver NPs could be a weak skin sensitiser. However, as stated above only $5 \%$ of animals were mildly sensitised (erythema score 1 after $48 \mathrm{~h}$ of challenging) in a regulatory study; while a second study failed demonstrating skin sensitisation power of silver NPs.

The amount of silver NPs intradermally injected to induce skin sensitisation in the positive study was around $60 \mathrm{mg} \mathrm{(3}$ injections of $0.1 \mathrm{ml}$ of a $20.48 \%$ preparation). Considering the worst exposure estimated in Table $2\left(2.8 \times 10^{-4} \mathrm{mg} / \mathrm{kg}\right.$ bw/ day) the number of days needed to reach $60 \mathrm{mg}$ of silver NPs from facemasks wearing would be around 3500 (assuming no elimination). Altogether, this suggests that, given the weak 
Table 3 Estimation of systemic DNEL for silver NPs

\begin{tabular}{|c|c|c|c|c|c|c|}
\hline & \multicolumn{2}{|c|}{$\begin{array}{l}\text { NOAEL (Kim et al. } \\
\text { 2010) }\end{array}$} & \multicolumn{2}{|c|}{$\begin{array}{l}\text { LOAEL (Kim et al. } \\
\text { 2010) }\end{array}$} & \multicolumn{2}{|c|}{$\begin{array}{l}\text { LOAEL (Yu } \\
\text { et al. 2014) }\end{array}$} \\
\hline & GP & W & GP & W & GP & W \\
\hline Critical value (mg/kg bw/day) & 30 & 30 & 125 & 125 & 100 & 100 \\
\hline Oral absorption & 0.18 & 0.18 & 0.18 & 0.18 & 0.18 & 0.18 \\
\hline \multicolumn{7}{|l|}{ Assessment factors } \\
\hline Interspecies allometric factor & 4 & 4 & 4 & 4 & 4 & 4 \\
\hline Interspecies remaining factor & 2.5 & 2.5 & 2.5 & 2.5 & 2.5 & 2.5 \\
\hline Intra-species factor & 10 & 5 & 10 & 5 & 10 & 5 \\
\hline LOAEL to NOAEL & 1 & 1 & 3 & 3 & 3 & 3 \\
\hline Adjustment to chronic & 2 & 2 & 2 & 2 & 6 & 6 \\
\hline Systemic DNEL (mg/kg bw/day) & 0.027 & 0.054 & 0.0375 & 0.075 & 0.010 & 0.020 \\
\hline
\end{tabular}

Critical values were taken from the referred studies summarised in Table 1. Oral absorption was taken from East et al. (1980). Assessment factors were set according to the ECHA procedures for deriving DNELs for threshold endpoints (ECHA 2012). The duration of the teratogenicity study (Yu et al. 2014) was considered sub-acute. $G P=$ General population, $W=$ Workers
Table 4 Risk characterisation for dermal exposure to silver NPcoated facemasks

\begin{tabular}{llll}
\hline & $\begin{array}{l}\text { Exposure (mg/kg } \\
\text { bw/day) }\end{array}$ & $\begin{array}{l}\text { DNELb (mg/kg } \\
\text { bw/day) }\end{array}$ & RCR \\
\hline General population & $7.0 \times 10^{-5}$ & 0.010 & 0.007 \\
Workers & $2.8 \times 10^{-4}$ & 0.020 & 0.014 \\
\hline
\end{tabular}

Exposure was extracted from Table 2. In a conservative approach the lowest DNEL estimated in Table 3 were extracted for estimation of risk characterisation ratio (RCR)

sensitising potential of silver NPs, the risk of skin sensitisation derived from wearing silver NPs coated facemasks is negligible. This is also supported by the fact that, approximately after 1.5 years of pandemic, no epidemiological studies reporting skins sensitisation were found in the open scientific literature.

\section{Genotoxicity}

The database provides an array of in vitro studies showing positive results. However, other in vitro studies contradicted these positive results. Moreover, regulatory in vivo studies did not obtain positive results. Even in the case that the positive results in vivo were not reproduced due to lack of accessibility of silver NPs to bone marrow, the positive in vitro results were obtained using silver concentration that are not physiologically feasible $(\mu \mathrm{g} / \mathrm{ml})$. Overall, the genotoxicity of silver NPs is still doubtful and more research as this regard is needed, although the in vitro available information suggests that the risk, if any, should be very low.

\section{Discussion of case 1}

We have estimated the risk of wearing silver NPs facemasks as regard as threshold effects, skin sensitisation and genotoxicity.
The results presented in this work suggest that the risk of skin sensitisation is negligible; while the risk for genotoxicity is very low. The risk for threshold effects is also very low; specifically, the exposure is 143 times lower than needed to cause hepatotoxicity in general population and 71 times in workers.

Our assessment describing the safety of wearing silver NPs coated masks is supported by the provisional tolerable intake derived for intravenous exposure to silver NPs released from medical devices. This provisional tolerable intake is $0.14 \mu \mathrm{g} /$ $\mathrm{kg}$ bw/day (Savery et al. 2017), therefore in the same order of magnitude that the systemic exposure obtained in Table 2 .

Our assessment for threshold effects has uncertainties. However, we consider that the estimated risk is overestimated because it has been suggested that silver NPs are indeed able to penetrate in vivo the stratrum corneum and reach reticular dermis, although silver NPs are deposited into the dermis and do not reach systemic circulation (George et al. 2014). This can be deduced from a study where a nanocrystalline silver dressing was applied to a sample of 16 healthy patients with normal intact skin and approximately after 5 days of exposure no increase in silver blood circulating could be detected (George et al. 2014).

We also estimated that our assessment is very conservative by a second reason. We used for setting the systemic DNEL the NOAEL and LOAEL considered in each of the key studies shown in Table 1 . These records are considered as very conservative. Kim and co-workers (2010) set a LOAEL based on mild haematological alterations suggesting hepatic impairments and bile-duct hyperplasia (with or without necrosis), fibrosis, and pigmentation. However, it is noted that the dose-response of these histopathological findings is unclear and therefore the liver impairment questionable. In addition, the teratogenicity study in rats (Yu et al. 2014) set a LOAEL based on oxidative stress in hepatic tissues; which could be also interpreted as an adaptive reaction to silver exposure rather than a liver 
malfunction at this exposure level. Thus, in none of these two key studies, a real liver impairment based on robust histopathological findings was consistently demonstrated.

\section{Case 2: graphene nanoparticles}

\section{Hazard identification}

\section{Threshold effects}

Our bibliographic search about adverse effects induced by graphene after repeated exposure reported six different studies (Table 5). As regard the route of exposure of these studies, one used intraperitoneal administration, two used inhalation exposure, two used gavage and one used drinking water as route of administration. Only one of these studies was considered with regulatory applicability (study 3 in Table 5).

In the intraperitoneal study (study 1 in Table 5) (Chong et al. 2014) it was noted that $20 \mathrm{mg}$ of polyethylene glycol graphene quantum (GQD-PEG) caused $25 \%$ of mortality (3/12 female Balb/c mice) without relevant alterations other than the darkening of liver and spleen. This allowed the authors to speculate that animals died by graphene bioaccumulation. However, this explanation is discussable since mortalities occurred on days 4, 5 and 6 of exposure and no other dead were reported between day 7 and 14 of exposure.

In a non-regulatory study, Kim and co-workers (2018) (study 2 in Table 5) were unable to detect toxicity in rats exposed up to $9.78 \mathrm{mg} / \mathrm{m}^{3}$ of graphene oxide nanopowder during 5 days ( $6 \mathrm{~h}$ /day). Similarly, non-significant toxicological effects were reported in a 28-day inhalation study performed observing OECD TG 412 in which rats were daily exposed during $6 \mathrm{~h}$ up to $1.88 \mathrm{mg} / \mathrm{m}^{3}$ of graphene nanoplatelets (Graphene REACH Registration dossier) (study 3 in Table 5).

Patlolla and co-workers (2016) (study 4 in Table 5) described kidney as target organ of graphene oxide after dosing rats by gavage during 5 days with up to $40 \mathrm{mg} / \mathrm{kg}$ bw/day. Indeed, this exposure regime induced haematological alterations together with severe histopathological alterations. On the opposite, Zhang and co-workers (2015) (study 5 in Table 6) failed to induce nephrotoxicity in mice treated by gavage with reduced graphene with $60 \mathrm{mg} / \mathrm{kg}$ bw/day. It is noted that, the graphene preparations used in studies 4 and 5 of Table 5 were different, since in the first case it as graphene oxide; while in the second it was reduced graphene and this difference could explain why Zhang and co-workers (2015) did not induce kidney alterations with a dose higher than Patlolla and co-workers (2016) did.
In a study with developing pups retardation in increase of body weight, body length and tail length were attributed to the graphene oxide exposure via drinking water. The authors attributed these alterations to noted decreased villus length of duodenum that could be reducing the efficiency of nutrient absorption (Fu et al. 2015) (study 7 in Table 5). On the contrary, in study 6 (Table 5) with graphene oxide, no nephrotoxicity was reported.

In addition to the above summarised and described repeated dose toxicity studies our bibliographic search also found some acute toxicity studies with graphene. Li and coworkers (2013) intratracheally instilled C57BL/6 mice with $0,1,5$ and $10 \mathrm{mg} / \mathrm{kg}$ of nanoscale graphene oxide finding substance aggregation followed by pulmonary inflammatory response, pulmonary parenchymal oedema, acute lung injury and chronic pulmonary fibrosis. In another intratracheal instillation study 5 and $50 \mu \mathrm{g}$ of few layer graphene (carbon/oxygen molar ratio $=89: 6)$ were administered to mice $(6$ animals/group) and $24 \mathrm{~h}$ after instillation in the $50 \mu \mathrm{g}$ group inflammatory cell infiltration together with lung cell injury were noted (Mao et al. 2016). Lungs of animals dosed with $50 \mu \mathrm{g}$ of few layer graphene turned black and showed mild to moderate interstitial oedema and parenchymal oedema together with the presence of multiple lung macrophages in the alveolis (Mao et al. 2016).

The literature also shows several in vitro toxicity studies with graphene. In this sense, concentrations up to $160 \mu \mathrm{g} / \mathrm{ml}$ of GQD-PEG did not induce after $24 \mathrm{~h}$ of exposure alterations in membrane integrity or mitochondrial function of HeLa cells and were also unable to induce oxidative stress and apoptosis (Chong et al. 2014). Nevertheless, Achawi and co-workers (2021) found after a systemic literature review considering 185 graphene NMs that there is a large variety of cytotoxic effects and that, with the available information, it is not possible to establish a clear structure-activity relationship for most of the materials due to their poor physical characterisation and the variety of biological end points employed in in vitro toxicity studies.

In summary, as usual, the specific nanoform, seems to play a pivotal role in the toxicity of the NP. The reported adverse effects in the assessed studies were dependent on route of exposure. Only after acute intratracheal instillation of graphene NMs severe pulmonary effects (pulmonary inflammatory response, pulmonary parenchymal oedema, chronic pulmonary fibrosis, inflammation) were reported; while the inhalation studies failed to reproduce such adverse effects; which suggests that pulmonary absorption could be notably low. The oral route studies also reported nephrotoxicity for same graphene forms. Finally, it is noted that no studies of toxicity using dermal route (the most relevant route for the exposure via facemasks) were found. 
Table 5 Summary of repeated dose toxicity studies in rodents with graphene NPs

\begin{tabular}{|c|c|c|c|}
\hline Study & Method & Results & Reference \\
\hline 1 & $\begin{array}{l}\text { GQD-PEG ( } 10-30 \mu \mathrm{m} \text { wide and } 0.5-2 \mathrm{~nm} \text { in height }) \\
\text { Balb/c mice } \\
12 \mathrm{females} / \text { group } \\
20 \mathrm{mg} / \mathrm{kg} / \text { day } \\
\text { Intraperitoneal injection } \\
14 \text { days }\end{array}$ & $\begin{array}{l}\text { 3/12 mortalities (days } 4,5 \text { and } 6 \text { ) } \\
\text { Died without any clinical signs } \\
\text { Animals with dark livers and spleens with dark spots with tens } \\
\text { of micrometers in diameter (presumably GQD-PEG bioac- } \\
\text { cumulation) } \\
\text { Blood biochemistry and haematology suggest no obvious toxic- } \\
\text { ity of GQD-PEG }\end{array}$ & Chong et al. 2014 \\
\hline 2 & $\begin{array}{l}\text { Graphene oxide nanopowder (thickness } 1 \sim 2 \text { atom layer) } \\
\text { Sprague-Dawley rats } \\
15 \text { males/group } \\
0,0.76,2.60 \text { and } 9.78 \mathrm{mg} / \mathrm{m}^{3} \\
\text { Nose-only inhalation exposure system } \\
6 \text { h/day } \\
5 \text { days } \\
\text { Recovery for } 1,3 \text {, and } 21 \text { days }\end{array}$ & $\begin{array}{l}\text { No significant body or organ weight changes } \\
\text { No effects on: blood biochemistry and haematology, bronchoal- } \\
\text { veolar lavage fluid inflammatory markers } \\
\text { No effects on bronchoalveolar lavage fluid lymphocytes, mac- } \\
\text { rophages, or polymorphonuclear cells } \\
\text { Spontaneous clearance of graphene oxide-ingested alveolar } \\
\text { macrophages } \\
\text { No histopathological lesions in liver and kidneys }\end{array}$ & Kim et al. 2018 \\
\hline 3 & $\begin{array}{l}\text { Graphene platelets (thicknesses, ranging from } 0.350 \text { to } 0.380 \mathrm{~nm} \text {, } \\
96 \% \text { carbon, } 4 \% \text { oxygen, } 750 \mathrm{~m}^{2} / \mathrm{g} \text { surface area of particles, } \\
0.2 \mathrm{~g} / \mathrm{ml},<2 \mu \mathrm{m} \text { average lateral dimension, } 20-30 \text { layers aver- } \\
\text { age thickness) } \\
\text { Nominal concentrations: } 0,0.12,0.47 \text { and } 1.88 \mathrm{mg} / \mathrm{m}^{3} \\
\text { Mass median aerodynamic diameter: } 123 \pm 3 \mathrm{~nm} \\
\text { Inhalation } \\
\text { Sprague-Dawley rats } \\
\text { OECD TG } 412 \\
\text { 28-days }\end{array}$ & $\begin{array}{l}\text { No clinical signs } \\
\text { No mortality } \\
\text { Significant body weight losses: } 0.47 \mathrm{mg} / \mathrm{m}^{3} \text { at week } 2 \text { and } \\
1.88 \mathrm{mg} / \mathrm{m}^{3} \text { at weeks } 1,5,6,11, \text { and } 13 \text { weeks } \\
\text { No toxicologically relevant or concentration-related haemato- } \\
\text { logical alterations } \\
\text { No concentration-related effects in the inflammatory or oxidative } \\
\text { stress biomarkers in the bronchoalveolar lavage fluid } \\
\text { No significant alterations in levels of various cytokines } \\
\text { In bronchoalveolar lavage fluid the total cell counts and mac- } \\
\text { rophage counts were significantly decreased in all the exposed } \\
\text { groups at the 1-day post-exposure and } 28 \text {-day post-exposure } \\
\text { Significant thymus weight loss and brain weight gain at the top } \\
\text { dose } \\
\text { No gross pathological findings } \\
\text { The ingested graphene in the lung macrophages persisted even } \\
\text { after the } 90 \text {-day post-exposure period }\end{array}$ & Kim et al. 2016* \\
\hline 4 & $\begin{array}{l}\text { Graphene oxide }(40 \mathrm{~nm} \text { diameter, zeta potential } \\
\quad \text { value }=-33.2 \mathrm{mV}) \\
\text { Sprague-Dawley rats } \\
5 \text { males } / \text { group } \\
0,10,20 \text { and } 40 \mathrm{mg} / \mathrm{Kg} \text { bw/day } \\
5 \text { days } \\
\text { Gavage }\end{array}$ & $\begin{array}{l}\text { Dose-dependent increase of the superoxide dismutase, catalase } \\
\text { and glutathione peroxidase activities in kidneys } \\
\text { Increase in serum creatinine and blood urea nitrogen levels } \\
\text { Significant elevation in the levels of lipid hydro peroxide } \\
\text { Significant histopathological alterations (progressive dilation of } \\
\text { tubules, tubular necrosis, renal tubular separation, degenera- } \\
\text { tion of hematopoietic tissue and tubular lumen) in kidneys }\end{array}$ & Patlolla et al. 2016 \\
\hline 5 & $\begin{array}{l}\text { Reduced graphene oxide nanosheets }(\sim 25 \mathrm{~mm}) \\
\text { C57black/6 mice } \\
5 \text { males/group } \\
60 \mathrm{mg} / \mathrm{kg} \text { body weight } \\
5 \text { days } \\
\text { Gavage } \\
1,15 \text { and } 60 \text { days recovery }\end{array}$ & $\begin{array}{l}\text { Open field test: No effect on the exploratory and anxiety-like } \\
\text { behaviours within } 60 \text { days of the final treatment } \\
\text { Rotarod test: On day } 1 \text { physical decline and decreased neuro- } \\
\text { muscular coordination; no effects on days } 15 \text { and } 60 \\
\text { Morris water maze test: Mouse learning and } \\
\text { memory not affected at any time } \\
\text { No effects on liver and kidney functions and haematology values } \\
\text { No dysfunction in hippocampus }\end{array}$ & Zhang et al. 2015 \\
\hline 6 & $\begin{array}{l}\text { Graphite oxide (carbon/oxygen molar ratio }=2.1 \\
\text { ICR mice } \\
6 \text { pups/group } \\
0,0.05 \text { and } 0.5 \mathrm{mg} / \mathrm{ml} \\
\text { Drinking water } \\
\text { Dose during post-natal days } 1-38 \\
\text { Observation at post-natal days } 21 \text { and } 38\end{array}$ & $\begin{array}{l}\text { No difference in behaviours } \\
0.5 \mathrm{mg} / \mathrm{ml} \text { : Retarded increase of body weight, body length and } \\
\text { tail length } \\
\text { No effects on blood biochemical indicators on kidney and liver } \\
\text { No morphological changes in lung, spleen, heart } \\
\text { and kidney at any dose and any time } \\
\text { Decreased villus length of duodenum at day } 38 \text { of } 0.5 \mathrm{mg} / \mathrm{ml} \\
\text { group }\end{array}$ & Fu et al. 2015 \\
\hline
\end{tabular}

* = Original study non-available to authors, data extracted from Graphene REACH registration dossier available on October 6 in https://echa. europa.eu/es/registration-dossier/-/registered-dossier/24678

\section{Skin sensitisation}

The Graphene REACH registration dossier presents a skin sensitisation study conducted observing OECD TG 406. This REACH registration dossier was presented for graphene platelets with thicknesses ranging from 0.350 to $0.380 \mathrm{~nm}$, a carbon/oxygen ratio $96 / 4$, a surface area of $750 \mathrm{~m}^{2} / \mathrm{g}$, a density of $0.2 \mathrm{~g} / \mathrm{ml}$, an average lateral dimension $<2 \mu \mathrm{m}$ and an average thickness of 20-30 layers. In this study, twenty male Hartley guinea pigs were induced $6 \mathrm{~h} /$ week for 3 weeks 


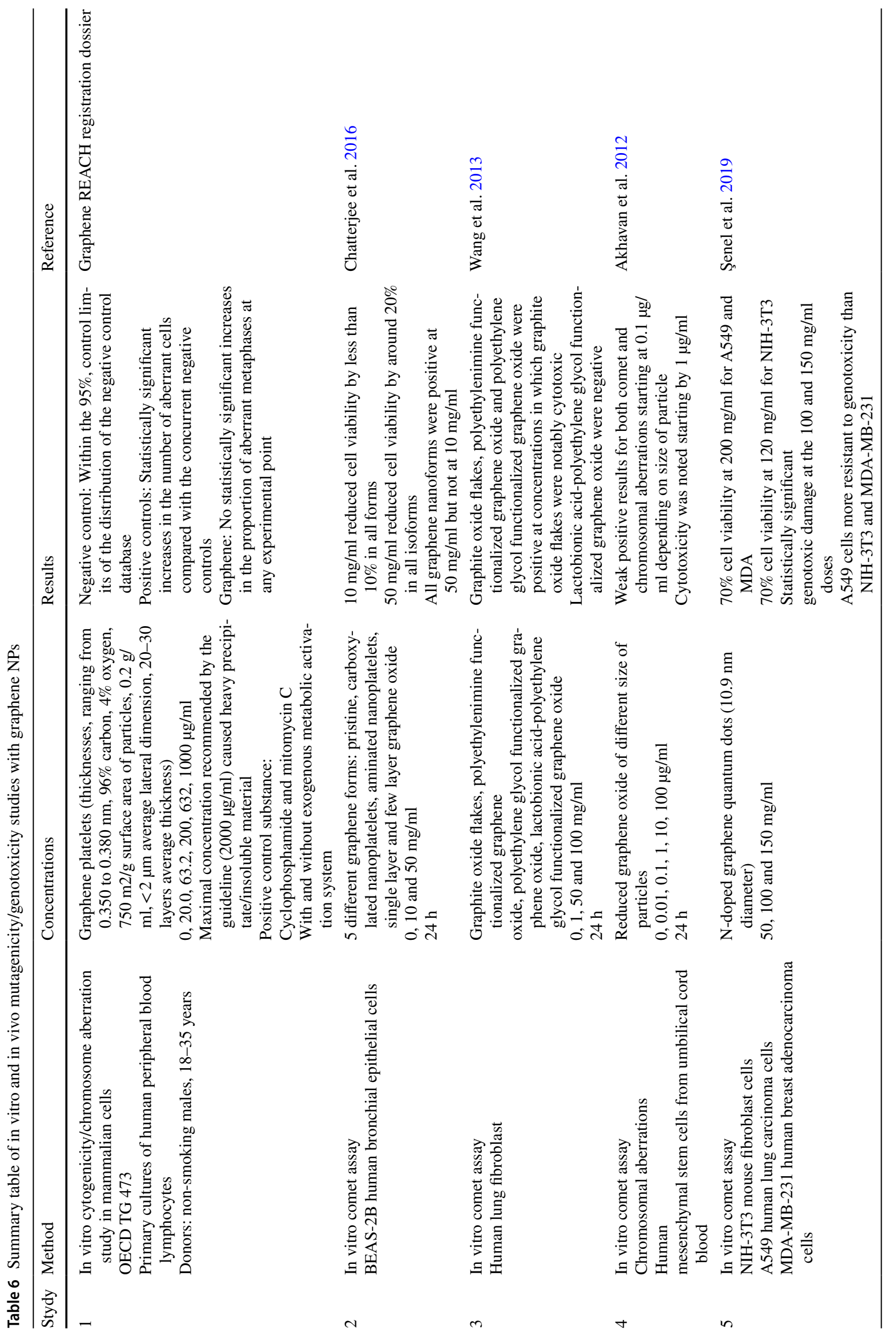




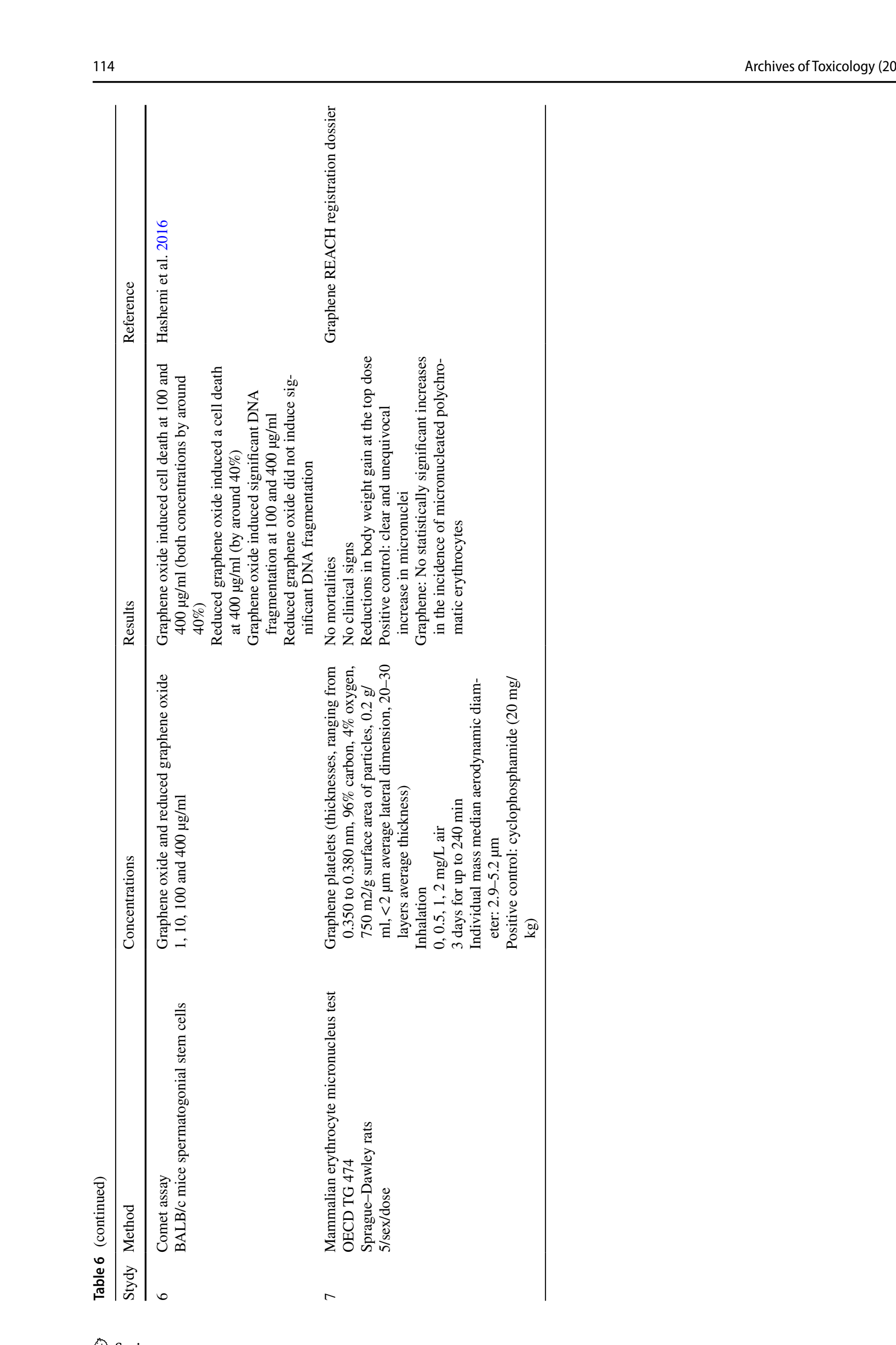


(days $1,8,15$ ) with $0.9 \%$ saline $+0.25 \mathrm{~g}$ graphene and on day 29 challenged during $6 \mathrm{~h}$ with $0.9 \%$ saline $+0.25 \mathrm{~g}$ graphene. In all cases, the exposure was epicutaneous with occlusive wrap. In parallel, control group and positive control groups (10 animals each) were induced with saline and challenged with $0.9 \%$ saline $+0.25 \mathrm{~g}$ graphene or $0.4 \mathrm{ml}$ $\alpha$-hexylcinnamaldehyde. There were no test substancerelated clinical observations or body weights alterations. No indication of skin sensitisation was noted neither 24 nor $48 \mathrm{~h}$ after challenge in animals induced with graphene; while animals induced with $\alpha$-hexylcinnamaldehyde showed positive indication of skin sensitisation. Thus, graphene is not a skin sensitiser under the conditions described in this study.

Kim and co-workers (2021) studied the skin sensitising potential of a graphene preparation (diameter $<2$ microns, and a thickness of a few $\mathrm{nm}$ and surface area of $300 \mathrm{~m}^{2} / \mathrm{g}$ ) using an in vitro assay (KeratinoSens ${ }^{\mathrm{TM}}$ Assay) and an alternative in vivo method (local lymph node assay with BALB/C mice). In the first in vitro test the EC1.5 (interpolated concentration for a 1.5-fold luciferase induction) value for the graphene NPs was higher than $2000 \mu \mathrm{M}$; which allows considering the preparation as a non-sensitizer. This result was confirmed in the local lymph node assay since the reported stimulation index was lower than three. Thus, the results of both tests support the above commented regulatory test and highlight again the fact that graphene is not a sensitising agent.

\section{Genotoxicity}

Our search about graphene genotoxicity yielded seven studies, six of them in vitro (one chromosome aberration study in mammalian cells plus five comet assays) and only one (a mammalian erythrocyte micronucleus test) in vivo. Only two of them were performed observing OECD Guidelines. These studies were summarised in Table 6.

The in vitro cytogenicity/chromosome aberration study in human peripheral blood lymphocytes (study 1 in Table 6) was performed observing OECD TG 473 and yielded a negative result. However, remaining in vitro comet studies shown in Table 6 (studies 2-6) with BEAS-2B human bronchial epithelial cells, human lung fibroblast cells, human mesenchymal stem cells from umbilical cord blood, mice spermatogonial stem cells and different human carcinoma cells yielded positive results. It is remarkable that some of these in vitro positive results were obtained at borderline concentrations to excessive cytotoxicity (studies 2, 4 and 5 ) or even with severe cytotoxicity (studies 3 and 6); which diminish the concern in front of a physiologically relevant exposure.

The in vivo mammalian erythrocyte micronucleus test in rats performed observing OECD TG 474 failed to detect statistically significant increase in the incidence of micronucleated polychromatic erythrocytes. Therefore, the positive in vitro results could not be confirmed by a regulatory study in vivo.

\section{Graphene absorption}

The relevant route of exposure in the case of facemasks wearing is dermal. However, no toxicological studies by dermal route were found in Table 5. Thus, as in the case of silver NPs, it is necessary to estimate the systemic (internal) exposure, and for such purpose, the absorption rates for different routes of exposure have to be considered.

\section{Oral absorption}

The oral route is not relevant for NPs exposure and we did not find robust information at this regard coming from standard toxicokinetic studies. Nevertheless, study 4 in Table 5 (Patlolla et al. 2016) showed, as graphene oxide is able to induce severe nephrotoxicity after gavage; which is a clear indicative that the NP has been absorbed to some extent. Zhang and co-workers (2015) concluded that reduced graphene oxide labelled with ${ }^{125}$ I was able to reach the main body organs after oral administration, although the percentage of absorption was not quantified in this study. However, this result is not supported by the findings reported by Yang and co-workers (2013); who noted that ${ }^{125}$ I labelled polyethylene glycolated graphene oxide was not obviously incorporated in tissues after oral administration, indicating the rather limited intestinal adsorption of these NMs. In conclusion, the oral absorption rate could not be deduced from the available database.

\section{Inhalation absorption}

The inhalation repeated dose toxicity studies summarised in Table 5 show no obvious adverse effects; which points towards a low absorption by inhalation. However, approximately $15 \%$ of ${ }^{125}$ I-polyethylene glycolated graphene oxide intratracheally instilled in mice was excreted in $6 \mathrm{~h}$ in urine indicating that the NM can penetrate the alveolar-capillary barrier into blood and be quickly eliminated by a renal route (Li et al. 2013). This study did not quantify the absorption, but Mao and co-workers (2016) confirmed the above-stated facts about the lack of oral absorption and estimated that $47 \%$ of few layer graphene labelled with ${ }^{14} \mathrm{C}$ remained in the lungs 4 weeks after intratracheal instillation.

\section{Dermal exposure}

Poland and co-workers (2013) reviewed the dermal absorption of NMs and concluded that there are conflicting 
results but, in general, the dermal absorption of any NM is theoretically feasible, although in low degree, especially for those NMs of large size, for which dermal absorption should be lower than those NMs of lower size.

We were unable to find studies about graphene dermal absorption. The REACH Registration dossier for graphene does not contain a dermal absorption study. However, this dossier presents an in vitro skin irritation study with reconstructed human epidermis. In this study, few layer graphene was found aggregated/agglomerated in the epidermis surface after 42 min of semi occlusive exposure. This study also reported few layer graphene depots smaller than the aggregates/agglomerates observed above the epidermis within the stratum corneum but not in inner skin layers. It suggested to the graphene registrant that the NM is not able to pass through stratum granulosum, stratum spinosum and stratum basale and therefore reach systemic circulation.

In conclusion, there is no relevant information about the graphene dermal absorption; although the limited available information suggests that the absorption should be rather low. This is also confirmed by Ou and co-workers (2016) when concluding that there is insufficient evidence available to conclude that graphene can penetrate skin. This is also supported by the fact that no information about dermal absorption of other carbon based NMs as single or multiple wall carbon nanotubes is available and by the fact that there is no indication that nanocarbon black (particle size $<40 \mathrm{~nm}$ ) used in cosmetics were absorbed through intact skin when measured with an imaging method (SCCS 2013).

\section{Systemic exposure}

Due to the above-stated unavailability of information about dermal absorption, it is concluded that it is not possible to derive a systemic exposure to graphene after dermal exposure derived from wearing facemasks coated with graphene.

\section{Systemic DNEL estimation}

The approach followed in case 1 is unfeasible in the case of graphene due to the impossibility to estimate a systemic exposure and also due to the impossibility to estimate a systemic DNEL due to lack of reliable information about absorption after inhalation or oral exposures. Thus, a non-quantitative risk assessment has been considered as appropriate.

\section{Risk characterisation}

\section{Threshold effects after repeated exposures}

The possibility of adverse effects after repeated dermal exposures cannot be totally ruled out due to the uncertainties addressed to dermal absorption, although the available information suggests that such dermal absorption, if any, should be very low and consequently, the adverse effects should be very unlikely.

\section{Skin sensitisation}

One regulatory assay performed observing OECD TG 406, one KeratinoSensTM in vitro test and one local lymph node assay yielded negative results when the tested substance was graphene. Thus, graphene is not a skin sensitiser and the dermal exposure derived from wearing graphene coated facemask does not pose a risk of skin sensitisation for both general population and workers.

\section{Genotoxicity}

Table 6 summarise the database for genotoxicity. Two regulatory (one in vivo and one in vitro) tests were negative, although an array of in vitro tests showed a few positive results sometimes in conditions producing cytotoxicity. The Guidance on the Application of the Classification, Labelling and Packaging Criteria (2017) published by ECHA establishes that a substance causes concerns of mutagenicity when there is positive evidence obtained from somatic cell mutagenicity tests in vivo, in mammals; or other in vivo somatic cell genotoxicity tests which are supported by positive results from in vitro mutagenicity assays. None of these conditions has been met for graphene and therefore the risk of genotoxicity derived from dermal exposure should not be considered a concern.

\section{Discussion of case 2}

We have detected important and relevant gaps in the database that precludes the possibility of a risk assessment with a reasonable uncertainty. These gaps affect mainly to dermal absorption that, although it seems it should be low, should be accurately determined.

The regulatory skin sensitisation test performed according to OECD TG was negative. However, it is noted that in this assay the induction phase was performed with dermal exposure instead of intradermal induction as usual. Considering the presumably low skin absorption, the result of this test flags some information gaps in terms of hazard 
identification, although the negative results in the in vitro and local lymph node assays reduce these concerns. Nevertheless, this uncertainty in hazard identification does not alter the result of the risk assessment that is maintained negligible due to the limited dermal absorption.

\section{General conclusions}

The risk assessment presented for both NMs suggests that, despite the uncertainties, the risk of adverse threshold, non-threshold and skin sensitisation effects derived from the wearing of silver or graphene coated NP face masks is low or even negligible. Therefore, the use of this protection device should be strongly encouraged to workers and general population as tool of defence against COVID-19.

We have reviewed the labels of several face masks coated with NMs and in none of them the amount and characteristic of the NM was available. The adverse effects of NMs depend, among other factors, of their physical properties. Thus, to perform further tier assessments, the physical characteristics of the coating NMs should be publically available. This would allow the regulatory agencies to conduct more refined risks assessments of these materials; thus, ensuring a safe use of this type of facemasks for consumer use.

\begin{abstract}
Author contributions CE had the idea. CE and MAS performed the literature search. All authors were involved in data analysis. MAS drafted the manuscript. All authors critically revised, enhanced and approved the manuscript.
\end{abstract}

Funding Open Access funding provided thanks to the CRUE-CSIC agreement with Springer Nature.

\section{Declaration}

Conflict of interest The authors declare that they have no conflict of interest.

Open Access This article is licensed under a Creative Commons Attribution 4.0 International License, which permits use, sharing, adaptation, distribution and reproduction in any medium or format, as long as you give appropriate credit to the original author(s) and the source, provide a link to the Creative Commons licence, and indicate if changes were made. The images or other third party material in this article are included in the article's Creative Commons licence, unless indicated otherwise in a credit line to the material. If material is not included in the article's Creative Commons licence and your intended use is not permitted by statutory regulation or exceeds the permitted use, you will need to obtain permission directly from the copyright holder. To view a copy of this licence, visit http://creativecommons.org/licenses/by/4.0/.

\section{References}

Abd EW, Eassa SM, Metwally M, Al-Hraishawi H, Omar SR (2020) SARS-CoV-2 transmission channels: a review of the literature. MEDICC Rev 22(4):51-69. https://doi.org/10.37757/MR2020. V22.N4.3

Achawi S, Pourchez J, Feneon B, Forest V (2021) Graphene-based materials in vitro toxicity and their structure-activity relationships: a systematic literature review. Chem Res Toxicol 34(9):20032018. https://doi.org/10.1021/acs.chemrestox.1c00243

Akhavan O, Ghaderi E, Akhavan A (2012) Size-dependent genotoxicity of graphene nanoplatelets in human stem cells. Biomaterials 33(32):8017-8025. https://doi.org/10.1016/j.biomaterials.2012. 07.040

Bianco C, Adami G, Crosera M, Larese F, Casarin S, Castagnoli C, Stella M, Maina G (2014) Silver percutaneous absorption after exposure to silver nanoparticles: a comparison study of three human skin graft samples used for clinical applications. Burns 40(7):1390-1396. https://doi.org/10.1016/j.burns.2014.02.003

Chatterjee N, Yang J, Choi J (2016) Differential genotoxic and epigenotoxic effects of graphene family nanomaterials (GFNs) in human bronchial epithelial cells. Mutat Res Genet Toxicol Environ Mutagen 798-799:1-10. https://doi.org/10.1016/j.mrgentox. 2016.01.006

Chong Y, Ma Y, Shen H, Tu X, Zhou X, Xu J, Dai J, Fan S, Zhang Z (2014) The in vitro and in vivo toxicity of graphene quantum dots. Biomaterials 35(19):5041-5048. https://doi.org/10.1016/j.bioma terials.2014.03.021

Cucinotta D, Vanelli M (2020) WHO declares COVID-19 a pandemic. Acta Biomed 91(1):157-160. https://doi.org/10.23750/abm.v91i1. 9397

East BW, Boddy K, Williams ED, Macintyre D, Mclay AL (1980) Silver retention, total body silver and tissue silver concentrations in argyria associated with exposure to an anti-smoking remedy containing silver acetate. Clin Exp Dermatol 5(3):305-311. https:// doi.org/10.1111/j.1365-2230.1980.tb01708.x

ECHA (European Chemicals Agency) (2012) Guidance on information requirements and chemical safety assessment Chapter R.8: characterisation of dose [concentration]-response for human health. Available in: https://echa.europa.eu/documents/10162/13632/infor mation_requirements_r8_en.pdf/e153243a-03f0-44c5-8808-88af6 6223258 (Accessed 6 Oct 2021)

Eikenberry SE, Mancuso M, Iboi E, Phan T, Eikenberry K, Kuang Y, Kostelich E, Gumel AB (2020) To mask or not to mask: Modeling the potential for face mask use by the general public to curtail the COVID-19 pandemic. Infect Dis Model 5:293-308. https://doi. org/10.1016/j.idm.2020.04.001

European Chemicals Agency (ECHA) (2017) Guidance on the application of CLP criteria. ISBN: 978-92-9020-050-5. https://doi. org/10.2823/124801. https://echa.europa.eu/documents/10162/ 23036412/clp_en.pdf/58b5dc6d-ac2a-4910-9702-e9e1f5051cc5 (Accessed 6 Oct 2021)

Fu C, Liu T, Li L, Liu H, Liang Q, Meng X (2015) Effects of graphene oxide on the development of offspring mice in lactation period. Biomaterials 40:23-31. https://doi.org/10.1016/j.biomaterials. 2014.11.014

Fuster E, Candela H, Estévez J, Arias AJ, Vilanova E, Sogorb MA (2020) Effects of silver nanoparticles on T98G human glioblastoma cells. Toxicol Appl Pharmacol 404:115178. https://doi.org/ 10.1016/j.taap.2020.115178 
Fuster E, Candela H, Estévez J, Vilanova E, Sogorb MA (2021) Titanium dioxide, but not zinc oxide, nanoparticles cause severe transcriptomic alterations in T98G human glioblastoma cells. Int J Mol Sci 22(4):2084. https://doi.org/10.3390/ijms22042084

George R, Merten S, Wang TT, Kennedy P, Maitz P (2014) In vivo analysis of dermal and systemic absorption of silver nanoparticles through healthy human skin. Australas J Dermatol 55(3):185-190. https://doi.org/10.1111/ajd.12101

Hadrup N, Lam HR (2014) Oral toxicity of silver ions, silver nanoparticles and colloidal silver-a review. Regul Toxicol Pharmacol 68(1):1-7. https://doi.org/10.1016/j.yrtph.2013.11.002

Hadrup N, Loeschner K, Bergström A, Wilcks A, Gao X, Vogel U, Frandsen HL, Larsen EH, Lam HR, Mortensen A (2011) Subacute oral toxicity investigation of nanoparticulate and ionic silver in rats. Arch Toxicol 86(4):543-551. https://doi.org/10.1007/ s00204-011-0759-1

Hashemi E, Akhavan O, Shamsara M, Daliri M, Dashtizad M, Farmany A (2016) Synthesis and cyto-genotoxicity evaluation of graphene on mice spermatogonial stem cells. Colloids Surf B Biointerf 146:770-776. https://doi.org/10.1016/j.colsurfb.2016.07.019

Jeong GN, Jo UB, Ryu HY, Kim YS, Song KS, Yu IJ (2010) Histochemical study of intestinal mucins after administration of silver nanoparticles in Sprague-Dawley rats. Arch Toxicol 84(1):63-69. https://doi.org/10.1007/s00204-009-0469-0

Johns Hopkins Coronavirus Resource Center (2021). https://coronavirus.jhu.edu/map.html (Accessed 6 Oct 2021)

Kim YS, Song MY, Park JD, Song KS, Ryu HR, Chung YH, Chang HK, Lee JH, Oh KH, Kelman BJ, Hwang IK, Yu IJ (2010) Subchronic oral toxicity of silver nanoparticles. Part Fibre Toxicol 7:20. https://doi.org/10.1186/1743-8977-7-20

Kim JK, Shin JH, Lee JS, Hwang JH, Lee JH, Baek JE, Kim TG, Kim BW, Kim JS, Lee GH, Ahn K, Han SG, Bello D, Yu IJ (2016) 28-Day inhalation toxicity of graphene nanoplatelets in Sprague-Dawley rats. Nanotoxicology 10(7):891-901. https:// doi.org/10.3109/17435390.2015.1133865

Kim YH, Jo MS, Kim JK, Shin JH, Baek JE, Park HS, An HJ, Lee JS, Kim BW, Kim HP, Ahn KH, Jeon K, Oh SM, Lee JH, Workman T, Faustman EM, Yu IJ (2018) Short-term inhalation study of graphene oxide nanoplates. Nanotoxicology 12(3):224-238. https://doi.org/10.1080/17435390.2018.1431318

Kim SH, Hong SH, Lee JH, Lee DH, Jung K, Yang JY, Shin HS, Lee J, Jeong J, Oh JH (2021) Skin sensitization evaluation of carbon-based graphene nanoplatelets. Toxics 9(3):62. https:// doi.org/10.3390/toxics9030062

Larese FF, D'Agostin F, Crosera M, Adami G, Renzi N, Bovenzi M, Maina G (2009) Human skin penetration of silver nanoparticles through intact and damaged skin. Toxicology 255(1-2):33-37. https://doi.org/10.1016/j.tox.2008.09.025

Li B, Yang J, Huang Q, Zhang Y, Peng C, Zhang Y, He Y, Shi J, Li W, Hu J, Fan C (2013) Biodistribution and pulmonary toxicity of intratracheally instilled graphene oxide in mice. NPG Asia Mater 5:e44. https://doi.org/10.1038/am.2013.7

Loeschner K, Hadrup N, Qvortrup K, Larsen A, Gao X, Vogel U, Mortensen A, Lam HR, Larsen EH (2011) Distribution of silver in rats following 28 days of repeated oral exposure to silver nanoparticles or silver acetate. Part Fibre Toxicol 8:18. https:// doi.org/10.1186/1743-8977-8-18

Mao L, Hu M, Pan B, Xie Y, Petersen EJ (2016) Biodistribution and toxicity of radio-labeled few layer graphene in mice after intratracheal instillation. Part Fibre Toxicol 13:7. https://doi. org/10.1186/s12989-016-0120-1

Matuschek C, Moll F, Fangerau H, Fischer JC, Zänker K, van Griensven M, Schneider M, Kindgen-Milles D, Knoefel WT, Lichtenberg A, Tamaskovics B, Djiepmo-Njanang FJ, Budach W, Corradini S, Häussinger D, Feldt T, Jensen B, Pelka R, Orth K, Peiper M, Grebe O, Maas K, Gerber PA, Pedoto A, Bölke E,
Haussmann J (2020) Face masks: benefits and risks during the COVID-19 crisis. Eur J Med Res 25(1):32. https://doi.org/10. 1186/s40001-020-00430-5

Ministry of Health of Canada Government (2013) Second report on human biomonitoring of environmental chemicals in Canada. Results of the Canadian Health Measures Survey Cycle 2 (2009-2011) ISBN: 978-1-100-22140-3. https://www.canada. $\mathrm{ca} /$ content/dam/hc-sc/migration/hc-sc/ewh-semt/alt_formats/ pdf/pubs/contaminants/chms-ecms-cycle2/chms-ecms-cycle2eng.pdf (Accessed 6 Oct 2021)

Morawska L, Cao J (2020) Airborne transmission of SARS-CoV-2: the world should face the reality. Environ Int 139:105730. https://doi.org/10.1016/j.envint.2020.105730

O’ Dowd K, Nair KM, Forouzandeh P, Mathew S, Grant J, Moran R, Bartlett J, Bird J, Pillai SC (2020) Face masks and respirators in the fight against the COVID-19 pandemic: a review of current materials advances and future perspectives. Materials (Basel) 13(15):3363. https://doi.org/10.3390/ma13153363

Organisation for Economic Cooperation and Development (2017) Series on the safety of manufactured nanomaterials No. 83: silver nanoparticles: summary of the dossier. https://www.oecd. org/officialdocuments/publicdisplaydocumentpdf/?cote=env/jm/ mono(2017)31\&doclanguage $=$ en $($ Accessed 6 Oct 2021)

Ou L, Song B, Liang H, Liu J, Feng X, Deng B, Sun T, Shao L (2016) Toxicity of graphene-family nanoparticles: a general review of the origins and mechanisms. Part Fibre Toxicol 13(1):57. https://doi.org/10.1186/s12989-016-0168-y

Patlolla AK, Randolph J, Kumari SA, Tchounwou PB (2016) Toxicity evaluation of graphene oxide in kidneys of sprague-dawley rats. Int J Environ Res Public Health 13(4):380. https://doi.org/ 10.3390/ijerph13040380

Poland CA, Read SAK, Varet J, Carse G, Christensen FM, Hankin SM (2013) Dermal Absorption of Nanomaterials. Published by The Danish Environmental Protection Agency. ISBN: 978-8793026-50-6. Available in: https://www2.mst.dk/Udgiv/publi cations/2013/09/978-87-93026-50-6.pdf (Accessed 6 Oct 2021)

Ramaiah GB, Tegegne A, Melese B (2021) Developments in nanomaterials and analysing its role in fighting COVID-19. Mater Today Proc. https://doi.org/10.1016/j.matpr.2021.05.020

REACH Register: Graphene. https://echa.europa.eu/es/registrationdossier/-/registered-dossier/24678 (Accessed 6 Oct 2021)

Savery LC, Viñas R, Nagy AM, Pradeep P, Merrill SJ, Hood AM, Malghan SG, Goering PL, Brown RP (2017) Deriving a provisional tolerable intake for intravenous exposure to silver nanoparticles released from medical devices. Regul Toxicol Pharmacol 85:108 118. https://doi.org/10.1016/j.yrtph.2017.01.007

Scientific Committee on Consumer Safety (SCCS) (2013) OPINION on carbon black (nano-form). ISBN 978-92-79-30120-9. https://doi. org/10.2772/7205. https://ec.europa.eu/health/scientific_commi ttees/consumer_safety/docs/sccs_o_144.pdf. (Accessed 6 Oct 2021)

Scientific Committee on Emerging and Newly Identified Health Risks (SCENIHR) (2014) Opinion on Nanosilver: safety, health and environmental effects and role in antimicrobial resistance. ISBN: 978-92-79-30132-2. https://doi.org/10.2772/76851. https://ec. europa.eu/health/scientific_committees/emerging/docs/scenihr_o_ 039.pdf. (Accessed 6 Oct 2021)

Şenel B, Demir N, Büyükköroğlu G, Yıldız M (2019) Graphene quantum dots: synthesis, characterization, cell viability, genotoxicity for biomedical applications. Saudi Pharm J 27(6):846-858. https://doi.org/10.1016/j.jsps.2019.05.006

Srivastava AK, Dwivedi N, Dhand C, Khan R, Sathish N, Gupta MK, Kumar R, Kumar S (2020) Potential of graphene-based materials to combat COVID-19: properties, perspectives, and prospects. Mater Today Chem 18:100385. https://doi.org/10.1016/j.mtchem. 2020.100385 
Tabatabaeizadeh SA (2021) Airborne transmission of COVID-19 and the role of face mask to prevent it: a systematic review and meta-analysis. Eur J Med Res 26(1):1. https://doi.org/10.1186/ s40001-020-00475-6

Tak YK, Pal S, Naoghare PK, Rangasamy S, Song JM (2015) Shapedependent skin penetration of silver nanoparticles: does it really matter? Sci Rep 5:16908. https://doi.org/10.1038/srep16908

United States Environmental Protection Agency (US-EPA) (2011b) Exposure factors handbook 2011 edition (Final Report). Chapter 8: body weight studies. https://cfpub.epa.gov/si/si_public_ record_report.cfm?Lab=NCEA\&dirEntryId=236252 (Accessed 6 Oct 2021)

United States Environmental Protection Agency (US-EPA) (2011a) exposure factors handbook 2011 edition (Final Report). Chapter 7: Dermal Exposure Factors. https://cfpub.epa.gov/si/si_public_ record_report.cfm?Lab=NCEA\&dirEntryId=236252 (Accessed 6 Oct 2021)

Wang A, Pu K, Dong B, Liu Y, Zhang L, Zhang Z, Duan W, Zhu Y (2013) Role of surface charge and oxidative stress in cytotoxicity and genotoxicity of graphene oxide towards human lung fibroblast cells. J Appl Toxicol 33(10):1156-1164. https://doi.org/10.1002/ jat. 2877

Yang K, Gong H, Shi X, Wan J, Zhang Y, Liu Z (2013) In vivo biodistribution and toxicology of functionalized nano-graphene oxide in mice after oral and intraperitoneal administration. Biomaterials
34(11):2787-2795. https://doi.org/10.1016/j.biomaterials.2013. 01.001

Yu WJ, Son JM, Lee J, Kim SH, Lee IC, Baek HS, Shin IS, Moon C, Kim SH, Kim JC (2014) Effects of silver nanoparticles on pregnant dams and embryo-fetal development in rats. Nanotoxicology 8(Suppl 1):85-91. https://doi.org/10.3109/17435390.2013.857734

Zhang D, Zhang Z, Liu Y, Chu M, Yang C, Li W, Shao Y, Yue Y, Xu $\mathrm{R}$ (2018) The short- and long-term effects of orally administered high-dose reduced graphene oxide nanosheets on mouse behaviors. Biomaterials 68:100-113. https://doi.org/10.1016/j.bioma terials.2015.07.060

Zhu N, Zhang D, Wang W, Li X, Yang B, Song J, Zhao X, Huang B, Shi W, Lu R, Niu P, Zhan F, Ma X, Wang D, Xu W, Wu G, Gao GF, Tan W (2020) China novel coronavirus investigating and research team a novel coronavirus from patients with pneumonia in China, 2019. N Engl J Med 382(8):727-733. https://doi.org/10. 1056/NEJMoa2001017

Publisher's Note Springer Nature remains neutral with regard to jurisdictional claims in published maps and institutional affiliations. 